\title{
Effect of Some Compounds on the $\alpha$ - Amylase Isoenzymes Activity purified from Abena-48 Wheat Flour Treated by Tribolium Confusum
}

\author{
Sameera M. Al-Katib \\ Department of Physiology \\ College of Veterinary Medicine \\ Mosul University \\ Received \\ Accepted \\ 24/3/2004 \\ $15 / 12 / 2004$
}

\section{الخلاصة}

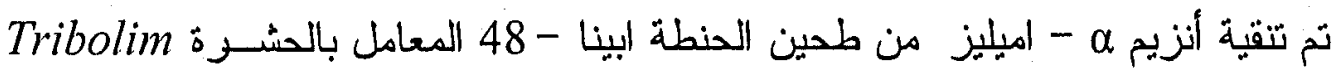

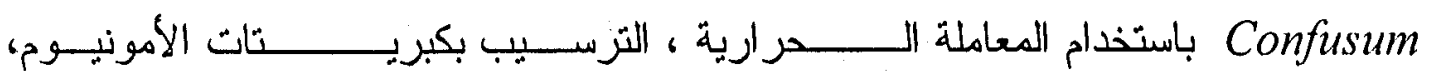

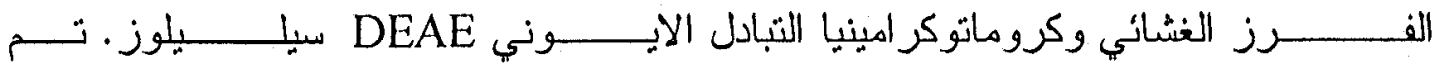

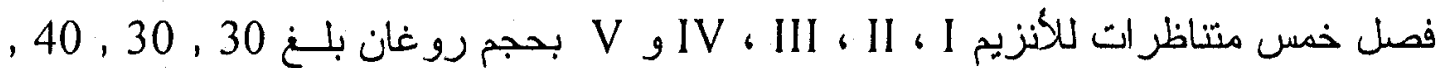
40و 20 مليلتر على التو الي، ويفعالية نو عبــة مقدارهـا 105120 ، 97333 ، 67384 ، 75703 ، 85800 وحدة إنزيمية / ملغم بروتين على التو الي مقارنة بالإنزيم الخام.

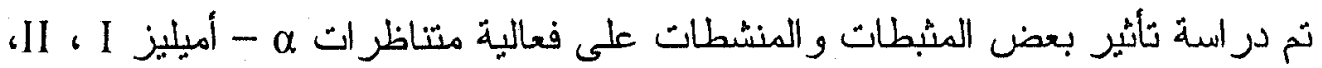

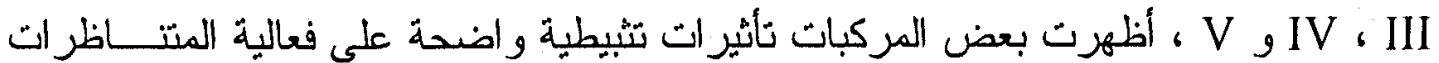

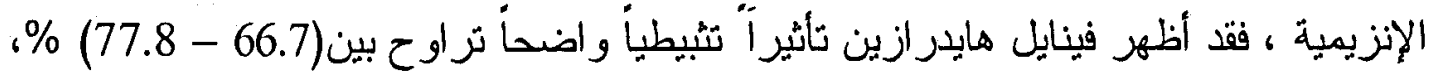

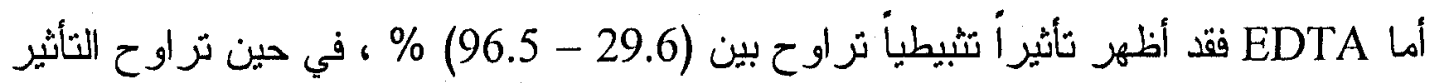

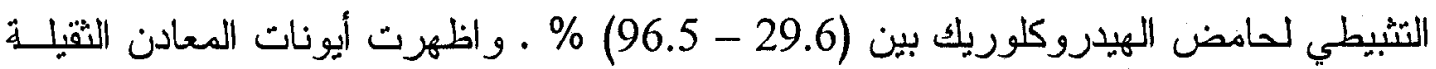

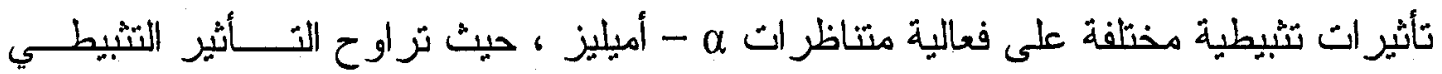
لــلبين

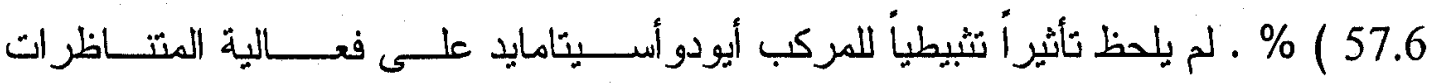

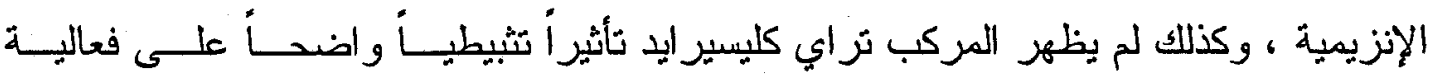

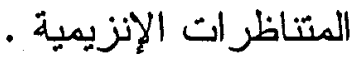
أظهرت أيونات الكالسيوم والكلور تأثير ات تحفيزية على فعالية منتاظر اته - أميالـــيز

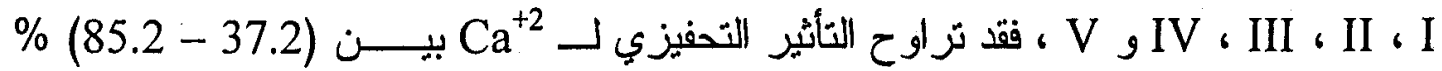

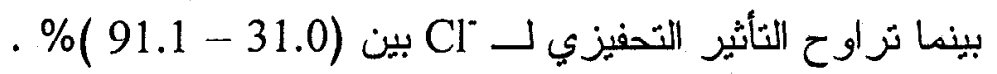




\section{ABSTRACT}

$\alpha$ - amylase was purified from Abena - 48 wheat flour treated by Tribolium confusum using heat treatment, ammonium sulfate precipitation ( $\mathrm{NH} 4)_{2} \mathrm{SO} 4$, dialysis and anion exchanger chromatography DEAE-cellulose. Five isoenzymes were optained I, II, III, IV \& V with elution volume of $30,30,40,40, \& 20 \mathrm{ml}$ respectively, and with specific activity of $105120,97333,67384,75703 \& 85800 \mathrm{mu} / \mathrm{mg}$ protein respectively compared with the crude enzyme. Effects of some inhibitors and activators on the $\alpha$ - amylase isoenzymes activity were studied. Phenyl hydrazine showed an inhibitory effect between $(66.7-77.8) \%$, EDTA showed an inhibitory effect between (29.6-96.5)\%, while the hydrochloric acid showed and inhibitory effect between (49.6-70.0)\%. Heavy metal ions showed a different inhibitory effects on the $\alpha$-amylase isoenzymes activity $\mathrm{Cu}^{+2}$ showed an inhibitory effect between (8.5$46.1) \%$, while $\mathrm{Fe}^{2}$ showed an inhibitory effect between (4.8-57.6)\%. No inhibitory effect was shown for iodoacetamide on the $\alpha$-amylase isoenzymes activity, and insignificant inhibitory effect was shown with Triglycerate.

Calcium and chloride ions showed activitory effects on the $\alpha$ - amylase isoenzymes activity $\mathrm{I}, \mathrm{II}, \mathrm{III}, \mathrm{IV} \& \mathrm{~V} . \mathrm{Ca}^{+2}$ showed an activitory effect between $(37.2-85.2) \%$, while $\mathrm{Cl}$ showed an activitory effect between $(31.0-91.1) \%$.

\section{INTRODUCTION}

The $\alpha$ - amylase (EC: 3.2 .1 .1 ) is one of the hydrolytic enzymes, it has ability to split polysaccharides $\alpha-1 \rightarrow 4$ linkage and form dextrins, maltose and glucose molecules (1). $\alpha$ - amylase is wide distribution in plants and animals (2), wheat and wheat flour $\alpha$ - amylase is an important enzyme in affecting the quality of wheat (3). $\alpha$ - amylase activity increases as a result of the insects which attacked the stored grains and its product and then cause a high damage of the commercial value (4). Tribolium confusum is one of the important insects that increased the $\alpha$-amylase activity (5). Special peptides and proteins are used as $\alpha$ - amylase inhibitors. Tendamistat is a proteinaceous inhibitor of $\alpha$-amylase activity $(6,7)$. Cyclic hexapeptides and cyclic tetrapeptides are another types of $\alpha$ amylase inhibitors (8), because of the difficulties to obtain such compounds so we study the effect of other compounds that affected $\alpha$ amylase activity. 


\title{
MATERIALS AND METHODS
}

Abena-48 wheat flour obtained from Mosul-flour factory. The adult Tribolium confusum had been taken from Mosul-flour factory and incubated at specific conditions of $27 \mathrm{c}^{\circ}$ and $70 \%$ humidity for 4 weeks.

\begin{abstract}
Assay of $\alpha$ - amylase:
$\alpha$-amylase activity of the extracts was determined by dinitro- salicylic acid method of Bendelow. The standard curve of maltose was determined by Nelson's colorimetric method of Bendelow (9) using aseries concentrations of maltose. The unit of the activity is ( $\mathrm{mu}$ ) which defined as the number of micromoles of $\alpha(1 \longrightarrow 4)$ glycosidic bonds hydrolyzed per minute.
\end{abstract}

\section{Protein determination:}

Protein in $\alpha$-amylase extracts and isoenzymes were determined by the modified lowry method (10).

\section{Purification of $\alpha$-amylase:}

$\alpha$-amylase has been extracted and purified as described in (11) with some modification. Sixty grams of treated wheat flour was stirred with $125 \mathrm{ml}$ of $0.05 \mathrm{M}$ calcium acetate buffer containing $0.1 \mathrm{M}$ calcium chloride for two hours at $4 \mathrm{c}^{\circ}$. The slurry was centrifuged at $9500 \mathrm{~g}$ for $10 \mathrm{~min}$., the supernatant was filtrated, and heated at $60 \mathrm{c}^{\circ}$ for $15 \mathrm{~min}$ at $\mathrm{pH} 6.6$ to inactivate $\beta$-amylase, then cooled in an ice bath, and centrifuged at $5000 \mathrm{~g}$. The filtrate dialyzed overnight against $0.2 \%$ calcium acetate. The dialysate fraction was loaded on DEAE-Cellulose column $(2.5 \times 40 \mathrm{~cm})$ with $0.05 \mathrm{M}$ calcium acetate buffer, $10 \mathrm{ml}$ fraction collected every $10 \mathrm{~min}$.

\section{$\alpha$-amylase effectors:}

Phenyl hydrazine, EDTA, $\mathrm{HCl}, \mathrm{CuSO}_{4}, \mathrm{FeSO}_{4}$, Iodoacetamide, Tristearin, $\mathrm{Cl}^{-}$and $\mathrm{Ca}^{+2}$, each at $0.6 \mathrm{~g} / 1$ concentration, were used for inhibition and activation studies. $\alpha$-Amylase isoenzymes I,II,III,IV\&V were preincubated with one or other of these inhibitors or activators for $30 \mathrm{~min}$. at $37 \mathrm{c}^{\circ}$ using the starch as substrate. The enzymatic activity was assayed using Bendelow method (9).

\section{RESULTS}

\section{a-Amylase purification:}

The results in table (1) showed that the specific activity of crude $\alpha$ amylase in wheat flour treated with Tribolium confusum was $21994 \mathrm{mu} / \mathrm{mg}$ protein, and the activity after heat treatment was 
$27186 \mathrm{mu} / \mathrm{mg}$ protein. Fig. (1) showed the elution profile obtained by purification of $\alpha$-amylase from abena -48 wheat flour treated with insect using DEAE-Cellulose. Five peaks were obtained, I, II, III, IV \& V with elution volume of (30-50), (70-90),(120-150),(170-200) and (220-230) $\mathrm{ml}$ respectively, and with respective specific activity of 105120,97333 , 67384,75703 and $85800 \mathrm{mu} / \mathrm{mg}$ protein. The purification folds were $4.78,4.43,3.06,3.44$ and 3.90 respectively compared with the crude enzyme ( table 1).

\section{Effect of inhibitors:}

Inhibitors in table (2), each with $0.6 \mathrm{~g} / 1$ concentration, showed a different effects on the $\alpha$-amylase isoenzymes I, II, III, IV \& V. Phenyl hydrazine inhibited the isoenzymes activity by $73.5 \%, 75.7 \% 69.1 \%$, $66.7 \%$, and $77.8 \%$ respectively. EDTA inhibited the isoenzymes activity by $57.6,96.5,33.5,53.7 \%$ and $29.6 \%$ respectively. $\mathrm{HCl}$ showed an inhibitory effect of $70.0 \%, 62.3 \%, 49.6 \%, 54.4 \%$ and $64.2 \%$ respectively. The heavy metal $\mathrm{Cu}_{+}{ }^{2}$ showed an inhibitory effect of $35.7 \%, 31.5 \%$, $8.4 \%, 46.1 \%$ and $29.6 \%$ for isoenzymes I, II, III, IV\&V respectively, (table 2). while $\mathrm{Fe}^{2}$ inhibited the isoenzymes activity I, II, III, IV, V by $57.6 \%, 37.7 \%, 4.8 \%, 38.9 \%$ and $49.0 \%$ respectively.

On the other hand, Iodoacetamide and Triglycerate showed a slightly inhibitory effect on the isoenzymes activity. Iodoacetamide inhibited the isoenzymes I, IV\&V by $7.2 \%, 23.5 \%$, and $3.5 \%$ respectively, while had no effect on the II\&III isoenzymes activity Triglycerate inhibited the isoenzymes I, II, III, IV, \& V by $7.6 \%, 19.2 \%$, $4.8 \%, 12.6 \%$ and $26.9 \%$ respectively (table 2 ).

\section{Effect of activators:}

The results in table (3) showed that chloride ion activated the $\alpha$ amylase isoenzymes I, II, III, IV, \& V by $50.3 \%, 56.9 \%, 91.1 \%, 31.0 \%$ and $75.4 \%$ respectively, while calcium ion showed an activitory effect of $56.6 \%, 37.2 \%, 85.2 \%, 60.6 \%$ and $58.8 \%$ respectively.

\section{DISCUSSION}

There were evidences that $\alpha$ - amylase had a high activity in abena wheat flour $(12,13)$ and Tribolium Confusum cause an increasing in the $\alpha$ amylase activity of abena - zero wheat flour (5) Now $\alpha$ - amylase activity was purified from abena-48 using extraction, heat treatment ammonium sulphate precipitation, dialysis, and ion exchange chromategraphy. In crude extract, $\alpha$ - amylase activity was $21994 \mathrm{mu} / \mathrm{mg}$ protein (table 1 ). $\alpha$ amylase was stable to heat, and heat treatment step was advantgeous in removing amounts of contaminating proteins such as $\beta$-amylase and 


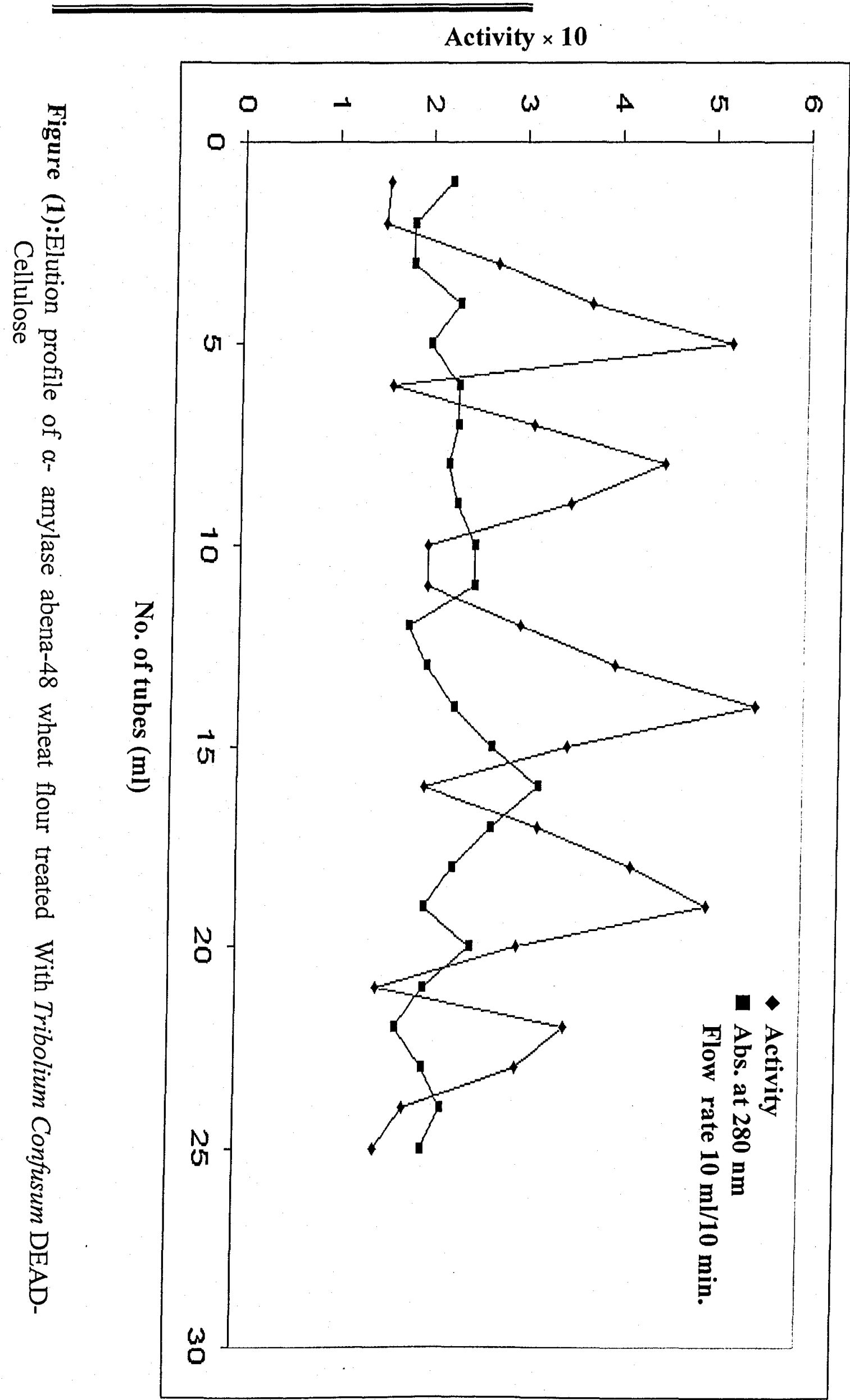

Abs. at $280 \mathrm{~nm} . \times 10$ 
Effect of Some Compounds on the $\alpha$-Amylase...

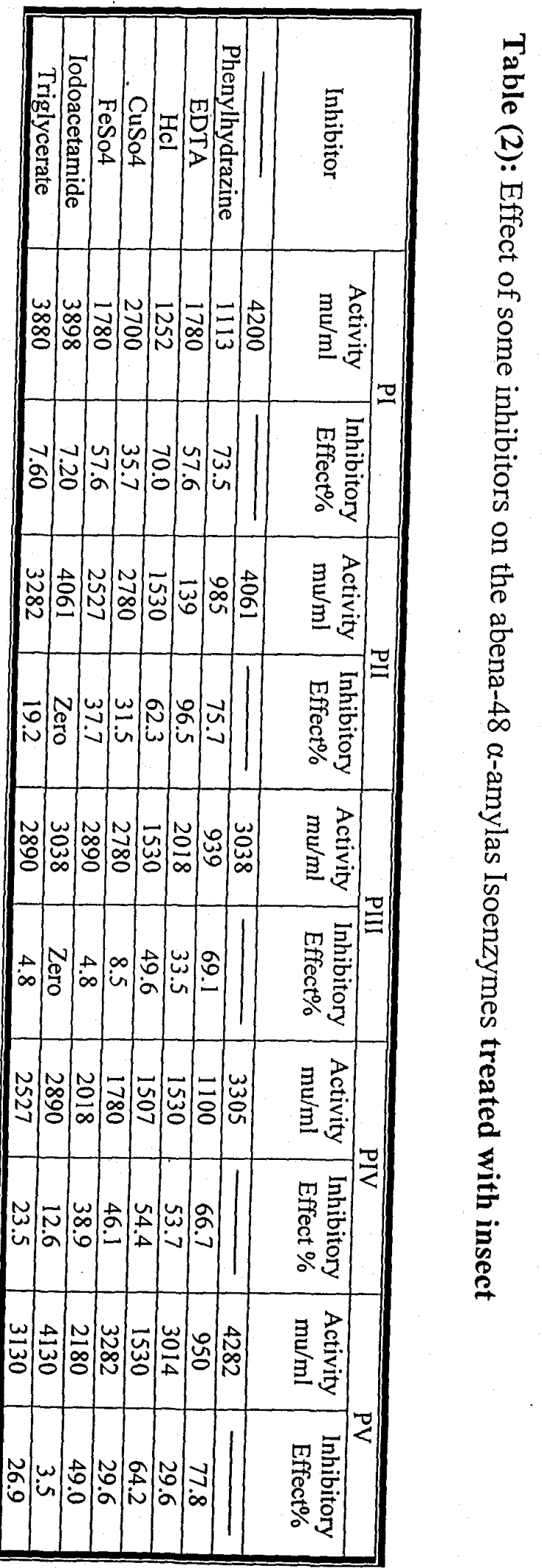




\begin{tabular}{|c|c|c|c|c|}
\hline 蛋 & $\Omega$ & & 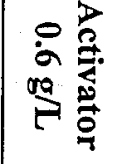 & \\
\hline$\vec{\Xi}$ & 荵 & 岇 & 最党: & \multirow{2}{*}{7} \\
\hline \%̆ & 望 & 1 & 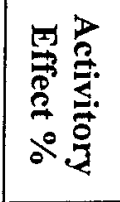 & \\
\hline 岕 & \begin{tabular}{|l}
$\mathbf{8}$ \\
岕 \\
$\infty$
\end{tabular} & 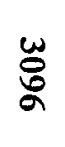 & 是营 & \multirow{2}{*}{ 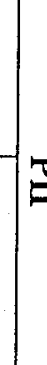 } \\
\hline$\underset{\sim}{\omega}$ & 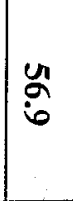 & 1 & 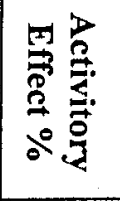 & \\
\hline$\underset{\infty}{\vec{\infty}}$ & 志 & $\stackrel{\tilde{N}}{\Omega}$ & 是总 & \multirow{2}{*}{$\underline{E}$} \\
\hline$\underset{i \sim n}{\stackrel{\infty}{*}}$ & $\stackrel{\bullet}{\dot{i}}$ & & 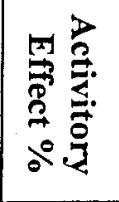 & \\
\hline $\begin{array}{l}\overrightarrow{0} \\
\text { O. }\end{array}$ & 突 & $\stackrel{\breve{ٌ ̆}}{\breve{u}}$ & 是总总 & \multirow{2}{*}{ 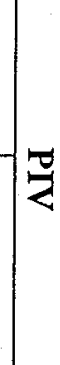 } \\
\hline ठे & $\stackrel{\omega}{\stackrel{\omega}{0}}$ & 1 & 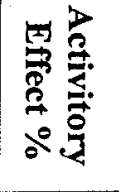 & \\
\hline $\begin{array}{l}\text { 密 } \\
\text { 足 }\end{array}$ & 㭊 & 岕 & 是总 & \multirow[b]{2}{*}{ 吾 } \\
\hline $\begin{array}{l}\infty \\
\infty \\
\infty\end{array}$ & $\begin{array}{l}\mathscr{n} \\
\dot{A}\end{array}$ & & 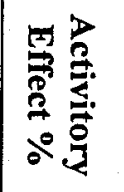 & \\
\hline
\end{tabular}




\section{REFERENCES}

1.Kaplan L.A. and Pesce, A.J. Clinical chemistry, U. S. A., Mosby 11011105 (1984).

2.Zakowski J.J. , Bruns D.E. Rev. Clin. Lab. Sci., 21: 283-322 (1985).

3.Appleman . Biochemical Microbilogical. New York. N .Y. consultants Bureau, 26 (5):488 (1991).

4.Jamil A.A.M., Master thesis, College of Science, University of Salahaddin (1990).

5.Lamia A.A., Samera M. and May K. I., Accebted in Rafjour. Sci. in press (2003).

6.Etzkorn felicia A. , Guo Tao J. Am. Chem. Soc., 116: 10414-10425 (1994).

7.Chen MS. , Feny G. , Zen K.C., Richadson M., Valdes S., Reeck GR. and Kramer K.J. Insect. Biochem. Mol. Biol. Exeter, Pregamon press. 22(3):261-268 (1992).

8.Matter H.K. and Horst J. Am. Chem. Soc., 117:3347-3359 (1995).

9.Bendelow V.M. J. Inst. Brew. , 69:467-470 (1963).

10.Schartrle G.R. and Pollack R.L. Anal. Biochem., 51:654-655 (1973).

11.Bilmanov M.K. , Furro D.V. and Frantser A.B. Nauka Alma-Ata., 92 (1974)

12.Lamia A.A. , Nahida S. A. and May K.I. J. Edu. Sci., 23:54-62 (1998).

13.Lamia, A.A. , Nahida S.A. and May K.I. J. Edu. Sci., 51:62-72 (2001).

14.Deohlent D.C. and Duke S.H. Am. Soc. Of plant physiol. 71 (2):229-234 (1983).

15.Nesterenko M.U. , Kuzovlev V.A. and Mosolou V.V. Apple. Biochem. Microbiol., New york, N.Y. consultants Bureau; 26 (5):483-485 (1991).

16.Sanwo M. , Demason and Darleen A . Inter. J. of plant Sci., 154: 395-405 (1993).

17.Stephen H.F. , Keith L.M., Heorge I.H.H. and Frank R.N.G. Biochemistry 19:3039-3047 (1980).

18.Fuller A.M. J. Sci. Fd. Agric. 21:26-30 (1970).

19.Murray R.K. , Garner D.K. , Mayes P.A. Harpers Biochemistry $24^{\text {th }}$ ed California, Appleton and Lange, 64: 82-88 (1996).

20.Marchylo B, Kruger JE., and Irvine GN., Cereal chemistry 53(2): 157173 (1978).

21.Marshall W.J. Clinical chemistry. $3^{\text {rd }}$ ed. Great Britain. Masby (1997).

22.Hsiu J. ; Fischer, E.H. ; Stein, E.A. Biochem. 3:61-66 (1964). 